\title{
Soil biological and biochemical traits linked to nutritional status in grapevine
}

\author{
P. Stevanato ${ }^{1 *}$, M. Bertaggia ${ }^{1}$, F. Stellin ${ }^{1}$, V. Rizzi ${ }^{2}$, P. Piffanelli², E. Angelini ${ }^{3}$, N. Bertazzon ${ }^{3}$, F. \\ Fornasier $^{4}$, A. Squartini ${ }^{1}$, M. Saccomani ${ }^{1}$, G. Concheri ${ }^{1}$
}

${ }^{1}$ Dipartimento di Agronomia Animali Alimenti Risorse Naturali e Ambiente, Università degli Studi di Padova, 35020 Legnaro (PD), Italy. ${ }^{2}$ Parco Tecnologico Padano, 26900 Lodi, Italy. ${ }^{3}$ Consiglio per la Ricerca e la Sperimentazione in Agricoltura, Centro di Ricerca per la Viticoltura, 31015 Conegliano (TV), Italy. ${ }^{4}$ Consiglio per la Ricerca e la Sperimentazione in Agricoltura, Centro di Ricerca per lo Studio delle Relazioni tra Pianta e Suolo, 34170 Gorizia, Italy. *Corresponding author: stevanato@unipd.it

\begin{abstract}
The purpose of this work was to study vineyards of NE Italy seeking for features associated to the soil or plant compartment that could serve as proxies to infer productivity of the grape. Soils were characterized for physicochemical properties, mineralization of organic matter by a novel patented device based on in-situ microbial degradation of buried fibers, bacterial intergenic spacer length diversity (ARISA), enzyme activities and the expression of genes involved in response to abiotic stresses. Significant differences $(p<0.05)$ were observed among vineyards for the parameters evaluated. The groupings obtained by ARISA were coherent with those obtained by PCA of soil properties. Vineyards endowed with higher productivity had soils showing higher enzyme activities along with neutral $\mathrm{pH}$, higher TOC content and appropriate $\mathrm{C} / \mathrm{N}$ ratio. These soils also showed higher mineralization of organic matter determined the novel in-soil thread degradation method. Grapevines of less productive vineyards had suboptimal leaf nitrogen and sulfur contents and showed up-regulation of WRKY, SuSY, PAL and STS1 genes. Results put in evidence useful correlations with yield that can be obtained up to several months earlier than harvest time upon analyzing selected indicators. An interesting link arises unifying soil biological properties, nutritional status, molecular stress response of grapevine and its production level.
\end{abstract}

Keyword: Soil biological properties, edaphic stresses, nutritional status, molecular stress response

\section{Introduction}

Soil properties, together with climate, directly affect vine development, berry composition and wine quality potential (Andrés-De Prado et al., 2007). Although soil biota are major drivers of biogeochemical cycles, little is known about their contribution to the production of quality wines. Soil relationships between fungal and bacterial community structure, enzyme activities and nutritional status of grapevines are not yet openly traced, although an increasing number of studies have highlighted the fundamental role of microbial processes in plant nutrition. Soil microorganisms control ecosystem functioning as mediators of carbon 
decomposition, carbon stabilization, and nutrient cycling (Coleman and Whitman, 2005). Particularly, they are a major source of enzymes required for plant access to nutrients (Reynolds et al., 2003). In addition, soil enzyme activities are good indicators of both microbial activity in soils, along with their prompt changes due to soil stresses, such as those due to by drought or heavy metal pollution (Badiane et al., 2001). Recent studies highlighted other fundamental ecosystem services mediated by microorganisms, emphasizing their role on ameliorating plant responses to soil stresses (Lau and Lennon, 2011). For instance, tolerance to edaphic stresses such as drought, salinity and heavy metals has been attributed to colonization by fungal endophytes (Rodriguez et al., 2008). These multi-faceted functions carried out by soil microorganisms contribute towards explanations of their promoting role on plant growth and productivity (Hol et al., 2010). New approaches in molecular biology are now being used to gain a deeper understanding of relationships between microbial community structure, enzyme activities and plant nutritional status. A simple and reliable technique suitable for analyzing structures of environmental microbial communities is ARISA. This PCR technique is based on the use of a fluorescent primer in the amplification of microbial ribosomal intergenic spacers, using DNA extracted from environmental samples as a template. This approach has been used successfully to assess the structure of soil bacterial and fungal communities (Ranjard et al., 2001; Cardinale et al., 2004). Advances in molecular genetics have also opened the way for a better understanding of soil-plant relationships and identification of defense-related genes in plants that could be involved in adaptation to edaphic stress. Numerous evidences indicate that plant responses to soil stresses are mediated by complex networks involving the expression of multiple genes (Kemp et al., 2005). In grapevine, many genes have been identified as being simultaneously regulated by abiotic and biotic stresses. For instance, phenylalanine ammonia lyase (PAL) and stilbene synthase 1 (VST1) encode key enzymes of the phenylpropanoid pathway, which leads to the production of various defense-related compounds like resveratrol (Ferrer et al., 2008; Gamm et al., 2011). Other genes, such as the sucrose synthase $(\mathrm{SuSy})$ and WRKY transcription factor, are involved in the metabolism of sucrose (Hren et al., 2009) and in the transcriptional reprogramming associated with plant immune responses (Marchive et al., 2007; Pandey and Somssich, 2009), respectively. The research described in this paper is a first attempt to link some soil biota characteristics to grapevine nutrition status. In addition to well-established techniques, we introduce in the present paper a new method for measuring microbial activity in soil (University of Padova, Italy, International Patent Cooperation Treaty n. PCT/ IB2012/001157, June 13, 2012, Squartini, Concheri, Tiozzo). It is based on the burying of cotton and silk threads in soil for a given time and subsequently measuring their residual resistance to breakage. Soils of four vineyards located in North-Eastern Italy were characterized for: i) physico-chemical properties; ii) biodegradation level of soil organic matter as indicated by means of degradation of threads of vegetal and animal origin; iii) soil enzyme activities; iv) bacterial community structure (ARISA fingerprinting). We also evaluated the expression of genes that could be involved in the defense mechanisms of grapevine to edaphic stresses. An integrated understanding of the complex associations among these traits could lead to actions targeted at enhancing natural nutrient cycling, re-equilibrating the nutritional status of plants and reducing dependence on mineral fertilizers in vineyard systems.

\section{Material and methods}

\subsection{Site description}

The study was conducted in four 15-year-old vineyards (cv. Garganega) grafted on $\mathrm{SO} 4$ rootstock and located in a hilly area near Gambellara, Vicenza, North-Eastern Italy. These vineyards were selected as the soil is representative of different soil types of commercial vineyards in the Gambellara area. The site is characterized by a humid subtropical climate 
with hot and humid summers and cool winters. The climate type under Koeppen's climate classification is Cfa (FAO-SDRN Agrometeorology Group, 1997). Annual precipitation has averaged $865 \mathrm{~mm}$ (since 1983), with the majority of precipitation falling between April and June. The mean annual temperature $\left({ }^{\circ} \mathrm{C}\right)$ was $13.4{ }^{\circ} \mathrm{C}$, with the average minimum daily temperature in January of $-2.0^{\circ} \mathrm{C}$ and the average maximum daily temperature in July of $30.8{ }^{\circ} \mathrm{C}$. Soils were classified following the criteria of the FAOUNESCO (IUSS, 2006) system and Soil Taxonomy (USDA-SCS, 1994).

\subsection{Analysis of soil physico-chemical properties}

Ten soil cores were collected from the vine rows at each of the four sampling sites. Soil core samples were placed in thermally-insulated boxes and transported to the laboratory. Samples were gently mixed and stored in plastic bags at $4{ }^{\circ} \mathrm{C}$. Soil features were determined after air-drying for 7 days at ambient temperature. Soil $\mathrm{pH}$ was measured in 1:2.5 soil:water suspensions using a glass electrode. Soil texture was determined using a Bouyoucos hydrometer following the method of Gee and Bauder (1986). Soil C and N content was measured with a CNS automatic analyzer (Elementar vario MACRO CNS, Elementar Analysen systeme GmbH, Hanau, Germany). Soil available phosphorus was extracted by shaking soil with a 0.5 $\mathrm{M}$ sodium hydrogen carbonate $\left(\mathrm{NaHCO}_{3}\right)$ solution (Olsen's P) for 30 min and determined by ICP-AES (Spectro Analytical Instruments, Kleve, Germany). Exchangeable bases $\mathrm{Ca}, \mathrm{Mg}$ and $\mathrm{K}$ were extracted by $0.1 \mathrm{~N}$ ammonium acetate $(\mathrm{pH} 7)$ and analysed according to Sharma et al. (1987).

\subsection{Analysis of bacterial soil communities by ARISA}

Whole genomic DNA was isolated from $500 \mathrm{mg}$ of three samples of soil collected in each of the four vineyards (12 samples in total) using the NucleoSpin ${ }^{\circledR}$ Soil (MACHEREY-NAGEL GmbH \& Co., Germany) according to the manufacturer's protocol. Quality of the isolated DNA was evaluated by spectroscopy
(220 $\mathrm{nm}$ to $340 \mathrm{~nm}$ ) and by running the sample in a $1 \%$ agarose gel stained with ethidium bromide $(\mathrm{Li}$, 2003). ARISA analysis was performed as described by Ranjard et al. (2001). The 16S rRNA intergenic spacer region from the bacterial rRNA operons was amplified using labeled primers. DNA were amplified in a $25 \mu \mathrm{L}$ reaction mixture containing 1x Mg-free Taq DNA polymerase buffer, $200 \mu \mathrm{M}$ of each dNTP, $1.5 \mathrm{mM} \mathrm{MgCl} 2,1 \mu \mathrm{M}$ of each primer, and 1 unit of Taq DNA polymerase. The PCR mix was held at $94{ }^{\circ} \mathrm{C}$ for $3 \mathrm{~min}$, followed by 30 cycles at $94{ }^{\circ} \mathrm{C}$ for $45 \mathrm{~s}, 55{ }^{\circ} \mathrm{C}$ for $1 \mathrm{~min}, 72{ }^{\circ} \mathrm{C}$ for 2 $\mathrm{min}$, and a final extension at $72^{\circ} \mathrm{C}$ for $7 \mathrm{~min}$. PCR amplicons were then discriminated in an ABI 3730 Genetic Analyzer (Applied Biosystems, CA, USA). ARISA PCR samples were run under standard ABI 3730 denaturing electrophoresis conditions using the Liz1200 marker, and the generated ARISA DNA fingerprint data were analyzed using the GeneMapper ver. 4 software (Applied Biosystems, CA, USA). The generated DNA fingerprint data were compared for similarity using the Numerical Taxonomy System software, Version 2.1 (NTSYSpc, Exeter Software, Setauket, New York, USA).

\subsection{Soil enzyme activities}

Soil enzyme activity was determined using soil extracts on microplates and fluorescent substrates. Soil extracts were obtained as follows: $0.5 \mathrm{~g}$ of soil were put in a $2 \mathrm{~mL}$ eppendorf tube together with $1 \mathrm{~mL}$ of a solution containing $4 \%$ bovine serum albumin and Triton X-100 (Fornasier and Margon, 2007) and glass beads. Tubes were subjected to bead-beating at 30 strokes $\mathrm{s}^{-1}$ for $3 \mathrm{~min}$, then centrifuged at $20,000 \mathrm{~g}$ for $5 \mathrm{~min}$. Supernatant containing desorbed enzymes was dispensed in 96-well microplates with appropriate buffer to determine enzymatic activity using fluorescent, 4-Methyl-umbelliferyl substrates. The following activities were determined: arylsulfatase, betaglucosidase, leucine-aminopeptidase and chitinase. 


\subsection{Analysis of soil biodegradation level}

The biodegradation level of organic matter by soil microorganisms was evaluated following a novel method and using a purposely defined device (University of Padova, Italy, PCT/IB2012/001157, June 13， 2012， Squartini， Concheri， Tiozzo) measuring the degradation of cotton and silk threads that are placed in the soil for a week. A small vertical hole was made in the soil with a spade, then threads (15 cm long) were carefully placed vertically and the hole was filled with soil. The extent of degradation of these threads, compared to that of unburied controls, is taken as an index of the cellulosolytic (cotton) or proteolytic (silk) attitudes of the soil microbial populations. In each vineyard, three sets of threads (untreated, pre-treated with nitrogen, pre-treated with phosphorus) per fiber (cotton and silk) were buried in two sites for a total of 12 threads (three treatments $x$ two fibers $\mathrm{x}$ two sites). The nitrogen- or phosphorus pre-treated versions of the threads, as defined by the above quoted patent, are used to assess to what extent such additions can further stimulate microbial activity in comparison to the plain untreated threads, i.e. whether availability of nitrogen or phosphorous limited thread decomposition. For this purpose they had been previously impregnated with different solutions containing $37.5 \mathrm{mM} \mathrm{NH} \mathrm{H}_{4} \mathrm{NO}$ (N-treated) or $42.3 \mathrm{mM} \mathrm{Na}_{2} \mathrm{HPO}_{4}, 22 \mathrm{mM} \mathrm{KH} \mathrm{PO}_{4}$ (P-treated), respectively. After a week, threads were gently extracted from the soil and air-dried. Their residual resistance to breakage was determined using a digital dynamometer (IMAD ZP, ELIS Electronic Instruments and Systems, Rome, Italy) to measure the peak force required to rupture them by applying progressive tractional force. The following formula was adopted to determine the thread resistance: $\mathrm{R}=$ (Ri / Rni) x 100 (where: $\mathrm{R}=$ resistance percentage; $\mathrm{Ri}=$ rupture value of the thread buried in the soil; Rni $=$ rupture value of a control filament when new). Resistance was converted into the degradation percentage (D) by subtracting resistance percentage values from 100 .

\subsection{Leaf nutritional status}

Twenty leaf samples per treatment were taken at flowering (June 22, 2010) and at veraison (onset of natural fruit color, August 11, 2010). The leaves were collected in the opposite first grape cluster area of an intermediate shoot on each vine branch. Three separate samples of 20 leaves were collected from each vineyard. Leaves were then surface-washed with distilled water, dried, pulverized and ashed at $450{ }^{\circ} \mathrm{C}$. Ashes were solubilized in $2 \mathrm{M} \mathrm{HCl}$ then element contents were determined by ICP-AES (Spectro Analytical Instruments, Kleve, Germany). Total nitrogen content was determined on untreated pulverized samples using combustion analysis (Elementar vario MACRO CNS, Elementar Analysensysteme $\mathrm{GmbH}$, Hanau, Germany).

\subsection{Analysis of gene expression}

Four selected defense-related genes (WRKY, SuSy, $P A L$ and STS1) were analyzed by real time qPCR (quantitative PCR) starting from total RNA of vine leaves collected from the vineyards on August 11, 2010. A set of five commonly used Vitis vinifera L. reference genes, encoding actin $(A C T)$, cytochrome oxidase $(C O X)$, pyruvate decarboxilase $(P D C)$, glyceraldehyde-3-phosphate dehydrogenase (GPDH) and 26S ribosomal RNA (26S), were used to normalize expression data (Bertazzon et al., 2012). Frozen leaves $(100 \mathrm{mg})$ were homogenized in liquid nitrogen and total RNA was extracted by means of the RNeasy Plant Mini Kit (Qiagen, Hilden Germany), using a protocol described by MacKenzie et al. (1997) with minor modifications. One $\mu \mathrm{g}$ of RNA was incubated with 1 unit of RNase-free DNase I (MBI Fermentas Heilderberg, Germany) for $45 \mathrm{~min}$ at $37{ }^{\circ} \mathrm{C}$ and the reaction was stopped with $1 \mu \mathrm{l}$ of $25 \mathrm{mM}$ EDTA. After denaturation at $95{ }^{\circ} \mathrm{C}$ for $5 \mathrm{~min}$, RNA was reverse transcribed at $42{ }^{\circ} \mathrm{C}$ for $50 \mathrm{~min}$ with Moloney Murine Leukemia Virus Reverse Transcriptase (M-MLV RT, Invitrogen, Catlsbad, CA) and oligo-dT primers. The primers for amplification of reference and target genes were designed based on sequences present in 
databases with Beacon Designer (version 2.13 Bio$\mathrm{Rad}$, Hercule, CA) software or they were selected from the literature. Sequences of primer pairs are available on request. Real-time PCR assays were conducted on a Bio-Rad thermal cycler (model iCycler IQ) in 96well plates using the 2X Platinum SYBR Green qPCR Supermix-UDG (Invitrogen). PCR reactions were performed at least in duplicate, in a total volume of $25 \mu \mathrm{l}$, including $0.3 \mu \mathrm{M}$ of each primer and $5 \mu \mathrm{l}$ of a 1:50 dilution of cDNA. The thermal protocol included a decontamination step of $3 \mathrm{~min}$ at $50^{\circ} \mathrm{C}$ to allow for optimal UDG (Uracyl DNA Glycosylase) enzymatic activity, followed by $3 \mathrm{~min}$ at $95^{\circ} \mathrm{C}$ in order to activate the Platinum Taq polymerase, deactivate the UDG and denature the DNA sample. Successively, 50 cycles of a two-step protocol, consisting of $15 \mathrm{~s}$ of denaturation at $95^{\circ} \mathrm{C}$ and $1 \mathrm{~min}$ of annealing/extension at $60^{\circ} \mathrm{C}$, were performed. Identical thermal cycling conditions were used for all targets. Performance quality of the newly designed real time primers, i.e. WRKY and PAL, and their assays was ensured by inspecting the run outputs. Regression coefficients in standard curves were always higher than 0.990, while PCR efficiencies ranged between 90 and 100\%. To normalize expression data, the five commonly used Vitis vinifera L. reference genes (ACT, COX, PDC, GAPDH, 26S RNA) were tested under the same experimental conditions (Bertazzon et al., 2012). NormFinder software (http://www.mdl.dk/ publications-normfinder.htm) was used to identify the two more stably expressed genes, which were then chosen for the normalization. Transcript levels were calculated with the comparative $\mathrm{Ct}(2-\Delta \Delta \mathrm{Ct})$ method (Schmittgen and Livak, 2008; Livak and Schmittgen, 2001), as all the primer pairs had similar amplification efficiencies.

\subsection{Data analysis}

The data were subjected to analysis of variance and correlation analysis using Statistica 10.0 package (StatSoft Inc., Tulsa, OK) and Fisher's Protected Least Significant Difference was calculated for mean comparison. Principal Component Analysis (PCA) of soil variables was performed using the multivariate analysis programs contained in the Statistica software package.

\section{Results}

Table 1 summarizes results related to the soils collected at $0-30 \mathrm{~cm}$ and $30-60$ depths in the four evaluated vineyards. They are characterized by a wide $\mathrm{pH}$ range (5.61 to 7.29). The TOC is low to medium (0.82-1.78). Vineyard 1 showed a low $\mathrm{C} / \mathrm{N}$ ratio (4.82) whereas the others displayed values ranging from 8.71 to 12.85 . All the vineyards are characterized by high contents of available phosphorus and medium to high contents of exchangeable bases (potassium, magnesium and calcium). However, the $\mathrm{Mg} / \mathrm{K}$ ratios resulted as suboptimal $(<2)$ in vineyard 1 . Soils showed limestone contents lower than $5 \%$ and were therefore classified as non-calcareous (AFES, 1992). pH, texture, CEC, available phosphorus and limestone of the samples collected at 30-60 cm soil depth showed values similar to those found in the top layer $(0-30 \mathrm{~cm})$. Instead, the deeper layer $(30-60 \mathrm{~cm})$ had a lower TOC content, a lower $\mathrm{C} / \mathrm{N}$ ratio (which was in the sub-optimal range) and lower potassium content.

The Principal Component Analysis (PCA) of the DNA fingerprint profiles obtained by ARISA of the bacterial communities present in the four examined soils enabled us to clearly discriminate them (Figure 1A). The three replicate soil samples collected from each of the vineyards were found to have very similar bacterial communities that clustered together in the PCA analysis, but were clearly separated from those collected in each of the other three vineyards. Moreover, the more productive soils (vineyards 3 and 4) were found to have a significantly different bacterial community from those of the other two vineyards. The differences in soil enzyme activities are shown in Table 2 from which it emerges that vineyard 4 appears endowed with significantly higher levels.

Table 3 shows the degradation of the buried reporter threads. Significant differences $(p<0.05)$ were detected among the sampling sites; degradation of silk threads was significantly higher $(p<0.05)$ than that of cotton ones. 
Table 1. Grape yield and selected physical and chemical properties of vineyard soils collected at 0-30 and 30-60 cm depths. Means followed by a different letter are significantly different (LSD-test, $p<0.05$ ).

\begin{tabular}{|c|c|c|c|c|c|c|c|c|c|c|c|c|c|}
\hline Vineyard & $\begin{array}{l}\text { Yield } \\
\left(t^{-1} a^{-1}\right)\end{array}$ & $\begin{array}{l}\text { Depth } \\
(\mathrm{cm})\end{array}$ & $\begin{array}{l}\mathrm{pH} \\
\left(\mathrm{H}_{2} \mathrm{O}\right)\end{array}$ & $\begin{array}{c}\text { CEC } \\
\left(\mathrm{meq}^{-1}\right) \\
\left.100 \mathrm{~g}^{-1}\right)\end{array}$ & $\begin{array}{r}\text { TOC } \\
(\%)\end{array}$ & $\begin{array}{c}\mathrm{N} \\
\left(\mathrm{g} \mathrm{kg}^{-1}\right)\end{array}$ & $\begin{array}{l}\mathrm{C} / \mathrm{N} \\
\text { ratio }\end{array}$ & $\begin{array}{l}\text { Avail. P } \\
\left(\mathrm{mg} \mathrm{kg}^{-1}\right)\end{array}$ & $\begin{array}{l}\text { Exch. K } \\
\left(\mathrm{mg} \mathrm{kg}^{-1}\right)\end{array}$ & $\begin{array}{c}\text { Exch. Mg } \\
\left(\mathrm{mg} \mathrm{kg}^{-1}\right)\end{array}$ & $\begin{array}{l}\mathrm{Mg} / \mathrm{K} \\
\text { ratio }\end{array}$ & $\begin{array}{l}\text { Exch. Ca } \\
\left(\mathrm{mg} \mathrm{kg}^{-1}\right)\end{array}$ & $\begin{array}{c}\text { Total } \\
\text { calcareous } \\
(\%)\end{array}$ \\
\hline 1 & $13.2 b$ & $0-30$ & $5.61 b$ & $23.8 \mathrm{~b}$ & $0.82 \mathrm{c}$ & $0.16 a$ & $5.13 c$ & 94.6 & $610.5 a$ & 792 & $1.31 \mathrm{~d}$ & $34 \mathrm{C}$ & $0.53 b$ \\
\hline$?$ & $13.5 \mathrm{~b}$ & $0-30$ & $7.29 a$ & $26.1 \mathrm{ab}$ & $1.36 \mathrm{~b}$ & $0.15 a$ & $9.07 \mathrm{~b}$ & $70.6 \mathrm{~b}$ & $611.5 a$ & 138 & $2.26 \mathrm{c}$ & 100 & $0.72 a$ \\
\hline 3 & $16.6 a$ & $0-30$ & $7.25 a$ & $29.4 a$ & $1.33 b$ & $0.13 b$ & $10.23 b$ & 46. & $489.6 \mathrm{~b}$ & 255 & $5.22 a$ & $7992.9 b$ & $0.33 d$ \\
\hline 4 & $17.9 a$ & $0-30$ & $6.92 a$ & $26.7 a b$ & $1.78 a$ & $0.13 b$ & $13.69 a$ & $51.8 \mathrm{c}$ & $613.5 a$ & $2198.1 a$ & $3.58 b$ & $7903.0 \mathrm{~b}$ & $0.42 \mathrm{c}$ \\
\hline 1 & $13.2 b$ & $30-60$ & $5.46 b$ & $18.6 c$ & $0.69 b$ & $0.16 a$ & $4.31 b$ & $100.4 a$ & $389.7 a$ & $891.2 d$ & $2.29 d$ & $3826.6 c$ & $0.64 a$ \\
\hline 2 & $13.5 b$ & $30-60$ & $7.24 a$ & $25.0 \mathrm{~b}$ & $0.66 b$ & $0.13 b$ & $5.08 b$ & $54.0 \mathrm{~b}$ & $253.8 b$ & $1569.6 c$ & $6.19 c$ & $10850.5 a$ & $0.73 a$ \\
\hline 3 & $16.6 a$ & $30-60$ & $7.31 \mathrm{a}$ & $30.1 a$ & $0.99 a$ & $0.13 b$ & $7.62 \mathrm{a}$ & $41.2 \mathrm{c}$ & $293.7 \mathrm{~b}$ & $2567.7 a$ & $8.74 b$ & $7983.0 \mathrm{~b}$ & $0.33 c$ \\
\hline 4 & $17.9 a$ & $30-60$ & $7.09 a$ & $22.6 b$ & $0.90 a$ & $0.12 b$ & $7.50 \mathrm{a}$ & $24.0 d$ & $128.3 \mathrm{c}$ & $2098.2 b$ & $16.4 a$ & $7413.5 b$ & $0.44 b$ \\
\hline
\end{tabular}
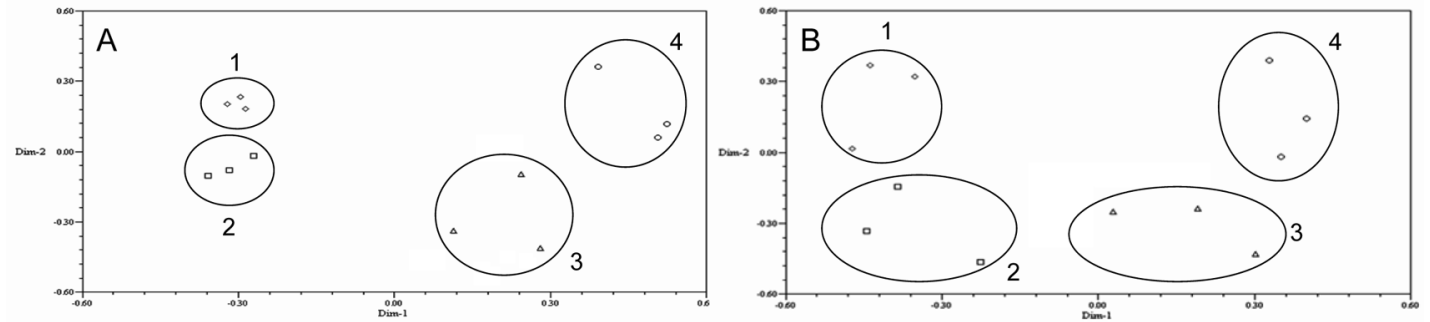

Figure 1. PCA analysis based on ARISA patterns (Figure 1A) and soil parameters (Figure 1B) evaluated in the four vineyards.

Table 2. Enzyme activities of vineyard soils. Means followed by a different letter are significantly different (LSDtest, $p<0.05)$.

\begin{tabular}{lcccc}
\hline \multirow{2}{*}{ Vineyard } & \multicolumn{4}{c}{ Enzymatic activity (a) } \\
\cline { 2 - 5 } & Arylsulfatase & $\begin{array}{c}\text { Beta- } \\
\text { glucosidase }\end{array}$ & $\begin{array}{c}\text { Leucine } \\
\text { aminopeptidase }\end{array}$ & Chitinase \\
\hline 1 & $6 \mathrm{~b}$ & $14 \mathrm{~b}$ & $48 \mathrm{~b}$ & $7 \mathrm{~b}$ \\
2 & $7 \mathrm{~b}$ & $12 \mathrm{~b}$ & $35 \mathrm{~b}$ & $9 \mathrm{~b}$ \\
3 & $10 \mathrm{~b}$ & $13 \mathrm{~b}$ & $53 \mathrm{~b}$ & $11 \mathrm{~b}$ \\
4 & $51 \mathrm{a}$ & $52 \mathrm{a}$ & $151 \mathrm{a}$ & $33 \mathrm{a}$ \\
\hline
\end{tabular}

(a) nM p-NP g-1 soil $\min ^{-1}$ 
Table 3. In-soil \% degradation of threads grouped by location, material (cotton or silk) and treatment (nitrogen or phosphorus). C: Control (non pre-treated) thread; N: pre-treated thread with nitrogen; P: pre-treated thread with phosphorus. Means followed by a different letter are significantly different (LSD-test, $p<0.05$ ).

\begin{tabular}{|c|c|c|c|c|c|c|c|}
\hline \multirow[t]{2}{*}{ Vineyard } & \multirow[t]{2}{*}{ Yield $\left(\mathrm{t} \mathrm{ha} \mathrm{a}^{-1}\right)$} & \multicolumn{3}{|c|}{ Cotton degradation (\%) } & \multicolumn{3}{|c|}{ Silk degradation (\%) } \\
\hline & & C & $\mathrm{N}$ & $P$ & C & $\mathrm{N}$ & $P$ \\
\hline 1 & $13.2 \mathrm{~b}$ & $-6.42 a b$ & $12.64 a b$ & $1.86 a b$ & $21.96 b$ & $32.33 a$ & $16.88 \mathrm{c}$ \\
\hline 2 & $13.5 b$ & $-0.25 a b$ & $5.23 b$ & $-1.89 b$ & $26.38 \mathrm{ab}$ & $30.51 \mathrm{a}$ & $48.98 a$ \\
\hline 3 & $16.6 a$ & $11.11 \mathrm{a}$ & $23.31 \mathrm{a}$ & $6.91 \mathrm{ab}$ & $29.91 \mathrm{a}$ & $24.89 a b$ & $37.23 b c$ \\
\hline 4 & $17.9 a$ & $2.22 \mathrm{ab}$ & 11.98ab & $8.66 a b$ & $26.38 \mathrm{ab}$ & $26.86 a b$ & $43.39 \mathrm{ab}$ \\
\hline
\end{tabular}

The predictive capability of the reporter cotton and silk threads is further visualized in Table 4, in which the Pearson correlation coefficients between thread degradation values and a number of parameters are shown along with their significance levels. It can be appreciated that grape yield is highly correlated $(0.774$ for cotton and 0.779 for silk) and at a strong statistically significant level $(p<0.01)$. PCA analysis performed using physico-chemical and microbiological soil data simultaneously highlighted a clear discrimination among vineyard sites (Figure 1B), with the most productive site vineyard 4 , being clearly distinguishable from the others.

Table 5 shows the results of leaf nutritional status measured on leaf samples collected at flowering (June 22) and veraison (August 11). It can be noticed that the content of different nutrients resulted as sufficiently high on both dates, with the exception of boron and zinc.

Table 4. Pearson correlation coefficients among in-soil \% degradation of threads, TOC content, $\mathrm{C} / \mathrm{N}$ ratio and grape yield (ns: not significant; ${ }^{*} p<0.05 ; * * p<0.01$ ). C: Control (non pre-treated) thread; N: thread pre-treated with nitrogen; P: thread pre-treated with phosphorus.

\begin{tabular}{|c|c|c|c|c|c|c|}
\hline & \multicolumn{3}{|c|}{ Cotton thread degradation (\%) } & \multicolumn{3}{|c|}{ Silk thread degradation (\%) } \\
\hline & C & $\mathrm{N}$ & $P$ & C & $\mathrm{N}$ & $\mathrm{P}$ \\
\hline TOC $(0-30 \mathrm{~cm})$ & ns & ns & ns & $0.650^{*}$ & ns & ns \\
\hline TOC $(30-60 \mathrm{~cm})$ & ns & $0.667^{\star}$ & ns & $0.706^{*}$ & ns & ns \\
\hline $\mathrm{C} / \mathrm{N}$ ratio $(0-30 \mathrm{~cm})$ & ns & ns & ns & $0.747^{* *}$ & ns & ns \\
\hline $\mathrm{C} / \mathrm{N}$ ratio $(30-60 \mathrm{~cm})$ & ns & $0.733^{* *}$ & ns & $0.803^{* *}$ & ns & ns \\
\hline Grape yield & $0.774^{* *}$ & $0.697^{*}$ & ns & $0.792^{* *}$ & ns & ns \\
\hline
\end{tabular}

On the appearance of symptoms of nutritional deficiency (leaf chlorosis), revealed on August 22, a third leaf analysis was carried out on vineyards 1 and 4 for comparison. Results revealed lower contents of nitrogen, sulfur and zinc in plants of vineyard 1 compared to those of vineyard 4 (Table 6).
Due to these differences between the two vineyards, we chose these sites to evaluate the expression of a set of genes involved in mechanisms counteracting adverse environmental conditions (WRKY, SuSy, PAL and $S T S 1$ ) because they could also be indicators of the vine nutritional status. 
Table 5. Content of micro- and macro-elements in grapevine leaves. Means followed by a different letter are significantly different (LSD-test, $p<0.05$ ).

\begin{tabular}{|c|c|c|c|c|c|c|c|c|c|c|}
\hline \multicolumn{11}{|l|}{ Flowering } \\
\hline Vineyard & $\begin{array}{l}\text { Yield } \\
\left(\mathrm{t} \mathrm{ha}^{-1}\right)\end{array}$ & $\begin{array}{c}\mathrm{N} \\
(\%)\end{array}$ & $\begin{array}{c}\mathrm{P} \\
\left(\mathrm{mg} \mathrm{kg}^{-1}\right)\end{array}$ & $\begin{array}{c}\mathrm{K} \\
\left(\mathrm{mg} \mathrm{kg}^{-1}\right)\end{array}$ & $\begin{array}{c}\mathrm{Mg} \\
\left(\mathrm{mg} \mathrm{kg}^{-1}\right)\end{array}$ & $\begin{array}{c}\mathrm{Ca} \\
\left(\mathrm{mg} \mathrm{kg}^{-1}\right)\end{array}$ & $\begin{array}{c}\mathrm{Fe} \\
\left(\mathrm{mg} \mathrm{kg}^{-1}\right)\end{array}$ & $\begin{array}{c}\mathrm{Mn} \\
\left(\mathrm{mg} \mathrm{kg}^{-1}\right)\end{array}$ & $\begin{array}{c}\mathrm{B} \\
\left(\mathrm{mg} \mathrm{kg}^{-1}\right)\end{array}$ & $\begin{array}{c}\mathrm{Zn} \\
\left(\mathrm{mg} \mathrm{kg}^{-1}\right)\end{array}$ \\
\hline 1 & $13.2 \mathrm{~b}$ & $2.64 a$ & $2183 a$ & $9548 a$ & $2890 a b$ & $15879 \mathrm{c}$ & $125 a$ & $389 a$ & $7.39 b$ & $28.0 a$ \\
\hline 2 & $13.5 \mathrm{~b}$ & $2.73 a$ & $1732 b$ & $7898 b$ & $1908 c$ & $25053 a$ & $112 a$ & $181 \mathrm{~b}$ & $8.00 \mathrm{ab}$ & $27.2 a$ \\
\hline 3 & $16.6 a$ & $2.47 a$ & $1749 b$ & $8763 a b$ & $2649 b$ & 24831b & $117 a$ & $72.0 \mathrm{~d}$ & $9.00 \mathrm{a}$ & $28.0 a$ \\
\hline 4 & $17.9 a$ & $2.62 a$ & $1660 \mathrm{~b}$ & $8965 a b$ & $3297 a$ & $27163 a$ & $110 a$ & $112 c$ & $9.00 \mathrm{a}$ & $24.0 a$ \\
\hline \multicolumn{11}{|l|}{ Veraison } \\
\hline Vineyard & $\begin{array}{l}\text { Yield } \\
\left(\mathrm{t} \mathrm{ha}^{-1}\right)\end{array}$ & $\begin{array}{c}\mathrm{N} \\
(\%) \\
\end{array}$ & $\begin{array}{c}\mathrm{P} \\
\left(\mathrm{mg} \mathrm{kg}^{-1}\right)\end{array}$ & $\begin{array}{c}\mathrm{K} \\
\left(\mathrm{mg} \mathrm{kg}^{-1}\right)\end{array}$ & $\begin{array}{c}\mathrm{Mg} \\
\left(\mathrm{mg} \mathrm{kg}^{-1}\right)\end{array}$ & $\begin{array}{c}\mathrm{Ca} \\
\left(\mathrm{mg} \mathrm{kg}^{-1}\right)\end{array}$ & $\begin{array}{c}\mathrm{Fe} \\
\left(\mathrm{mg} \mathrm{kg}^{-1}\right)\end{array}$ & $\begin{array}{c}\mathrm{Mn} \\
\left(\mathrm{mg} \mathrm{kg}^{-1}\right)\end{array}$ & $\begin{array}{c}\mathrm{B} \\
\left(\mathrm{mg} \mathrm{kg}^{-1}\right)\end{array}$ & $\begin{array}{c}\mathrm{Zn} \\
\left(\mathrm{mg} \mathrm{kg}^{-1}\right)\end{array}$ \\
\hline 1 & $13.2 b$ & $2.34 a$ & $1396 b$ & $8228 a$ & $3135 a$ & $16224 b$ & $106 \mathrm{c}$ & $177 a$ & $7.86 a$ & $22.2 a$ \\
\hline 2 & $13.5 b$ & $1.97 a b$ & $1469 b$ & $7760 a$ & $1855 b$ & $24880 a$ & $113 b c$ & $143 b$ & $8.13 a$ & $20.9 a$ \\
\hline 3 & $16.6 a$ & $1.75 b$ & $1736 a$ & $8264 a$ & $3132 a$ & $25391 a$ & $134 a$ & $86 c$ & $8.30 \mathrm{a}$ & $19.2 b$ \\
\hline 4 & $17.9 a$ & $2.05 \mathrm{ab}$ & $1505 a$ & $7824 a$ & $3606 a$ & $26701 a$ & $112 b c$ & $100 c$ & $7.59 a$ & $20.5 a$ \\
\hline
\end{tabular}

Table 6. Content of micro- and macro-elements in grapevine leaves of vineyards 1 and 4 at August 22, 2010. Means followed by a different letter are significantly different (LSD-test, $p<0.05$ ).

\begin{tabular}{lcccccccccc}
\hline Vineyard & $\begin{array}{c}\text { Yield } \\
\left(\mathrm{t} \mathrm{ha}^{-1}\right)\end{array}$ & $\begin{array}{c}\mathrm{N} \\
(\%)\end{array}$ & $\begin{array}{c}\mathrm{P} \\
\left(\mathrm{mg} \mathrm{kg}^{-1}\right)\end{array}$ & $\begin{array}{c}\mathrm{K} \\
\left(\mathrm{mg} \mathrm{kg}^{-1}\right)\end{array}$ & $\begin{array}{c}\mathrm{Mg} \\
\left(\mathrm{mg} \mathrm{kg}^{-1}\right)\end{array}$ & $\begin{array}{c}\mathrm{Ca} \\
\left(\mathrm{mg} \mathrm{kg}^{-1}\right)\end{array}$ & $\begin{array}{c}\mathrm{Fe} \\
\left(\mathrm{mg} \mathrm{kg}^{-1}\right)\end{array}$ & $\begin{array}{c}\mathrm{Mn} \\
\left(\mathrm{mg} \mathrm{kg}^{-1}\right)\end{array}$ & $\begin{array}{c}\mathrm{Zn} \\
\left(\mathrm{mg} \mathrm{k}^{-1}\right)\end{array}$ & $\begin{array}{c}\mathrm{B} \\
\left(\mathrm{mg} \mathrm{kg}^{-1}\right)\end{array}$ \\
\hline 1 & $13.2 \mathrm{~b}$ & $1.34 \mathrm{~b}$ & $2103 \mathrm{a}$ & $10567 \mathrm{a}$ & $3310 \mathrm{a}$ & $17200 \mathrm{a}$ & $151 \mathrm{a}$ & $236 \mathrm{a}$ & $20.2 \mathrm{a}$ & $13.4 \mathrm{a}$ \\
4 & $17.9 \mathrm{a}$ & $2.38 \mathrm{a}$ & $2300 \mathrm{a}$ & $12167 \mathrm{a}$ & $3740 \mathrm{a}$ & $20100 \mathrm{a}$ & $156 \mathrm{a}$ & $198 \mathrm{a}$ & $38.5 \mathrm{a}$ & $12.6 \mathrm{a}$ \\
\hline
\end{tabular}

Values of relative expression of these four genes, compared with respect to the constitutively expressed glyceraldehyde-3-phosphate dehydrogenase gene $(G A P D H)$ are shown in Figure 2. The four genes showed significantly higher $(p<0.001)$ expression values at the site 1 than at site 4 , showing a correspondence between visual symptoms of plant suffering and responses at molecular level.

\section{Discussion}

Data allow several considerations. In terms of soil chemistry, the low TOC and $\mathrm{C} / \mathrm{N}$ ratio displayed by vineyard 1 may be due to the use of agronomic practices such as land leveling and deep plowing prior to vineyard plantation. Moreover, most European vineyard soils have low soil organic matter content and, therefore, they are low in water holding capacity and nitrate retention (Schmidt et al., 2014). The supply of organic matter is considered a pre-requisite for a reequilibrium of nutritional disorders (Fregoni, 2009). Therefore, to encourage this process and promote the formation of stable humus, inputs of cellulose and lignin-rich materials with high $\mathrm{C} / \mathrm{N}$ ratios (at least 1020) are needed (Oliver et al., 2013). The grouping of vineyards based on PCA analysis of physico-chemical and microbiological soil parameters was very similar to that obtained by the ARISA fingerprinting, suggesting that good microbiological properties parallel good mineral nutrition in grapevine. It may therefore be hypothesized that the microbial communities in vineyards 3 and 4 contribute to a better mineral nutrition of the grapevine plants. This hypothesis is supported by differences in soil enzyme activities. 


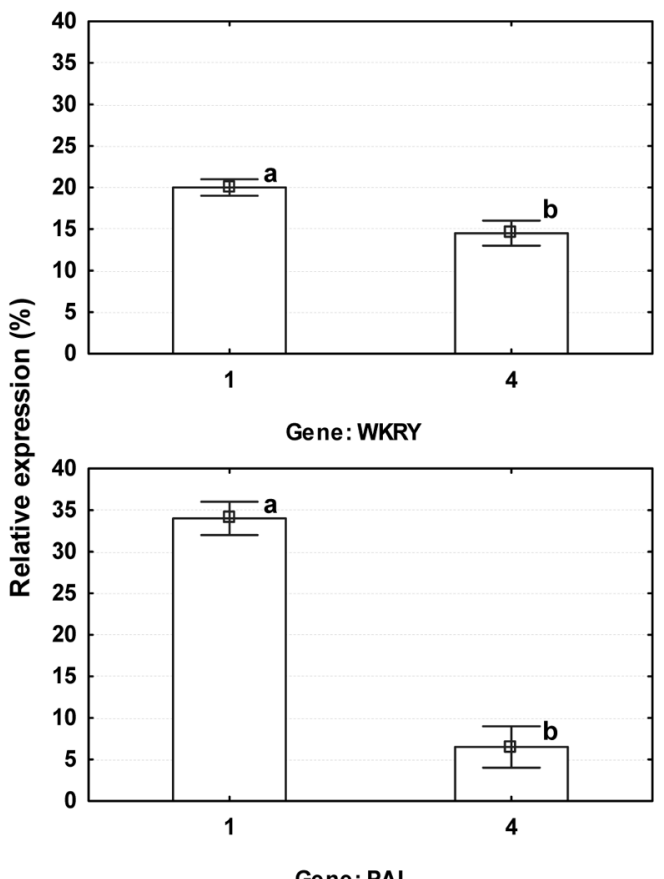

Gene: PAL
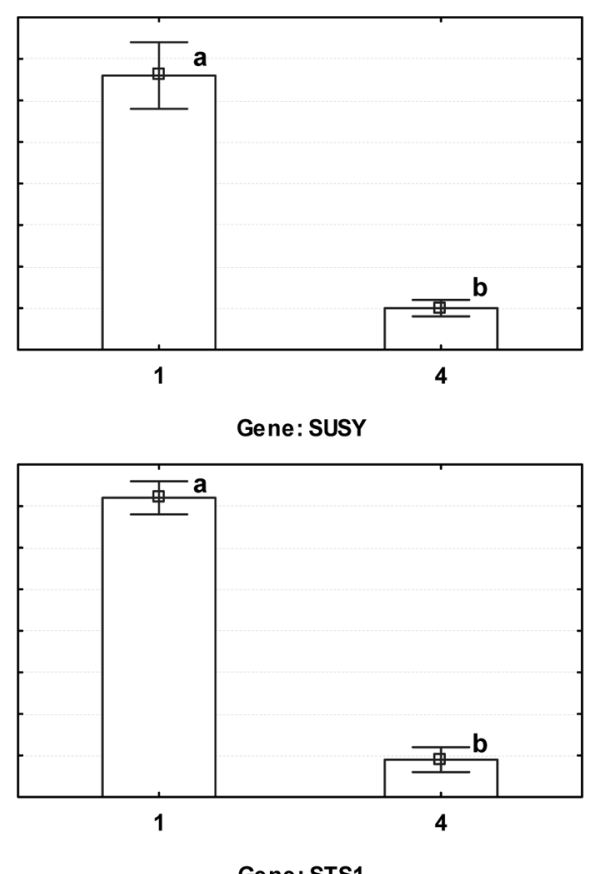

Vineyard

Figure 2. Relative expression of WRKY, SuSy, PAL e STS1 genes in grapevine tissues from vineyards 1 and 4 evaluated through RT-qPCR. Means followed by a different letter are significantly different (LSD-test, $p<0.05$ ).

In fact, vineyard 4 displayed a much higher enzymatic activity than the other vineyards. This result suggests a link between biochemical activity, microbial community and grape nutritional status.

As regards the use of the cotton and silk fibers, these proved to be effective indicators of soil fertility, the response of the $\mathrm{N}$-supplemented thread appears in addition a valuable proxy for soil organic carbon and soil $\mathrm{C} / \mathrm{N}$ ratio in the deep layers (30-60 $\mathrm{cm}$ ), while the untreated silk fiber is correlated with all parameters examined. Given the fundamental contribution of microbial activity as a mediator in mineralization and recycling of elements to the benefit of plant nutrition (Marschner, 1995), the reporter activity of the threads and its statistically supported relationships with productivity turn out to be a valuable meter for the assessment of soil attitudes and the prediction of plant performance. Degradation of silk threads was more pronounced than that of cotton ones, suggesting a particularly intense proteolytic activity of the microbial biomass with respect to cellulolytic activity. Yearly inputs of organic matter of animal origin (manure pellets) are indeed received by the evaluated vineyards. This type of agronomic practice is known to induce the establishment of proteolytic microbial communities rather than cellulolytic ones; in fact the latter are stimulated by organic matter from plant origin (Florenzano, 1986). 
The gene expression analyses turned out also highly informative. The differences in gene expression could be attributable to the nitrogen and sulfur deficiencies revealed in plants of vineyard 1 compared to those of vineyard 4 . These plant responses at the molecular level could have a crucial role in the adaptation strategies of grapevine in the presence of nutritional stress. It should be noted that overexpression of genes coding for molecules such as those involved in resveratrol synthesis, which are endogenous defenses as a result of moderate environmental stress, may contribute to raising the quality of wines (Fregoni, 2009). Further developments on molecular response to stresses could reveal subtle, yet very important, relationships between the molecular alterations found in the grapevine and any appreciable changes in the organoleptic quality of the wine. Besides, the results also evidenced that GAPDH and $A C T$ genes, out of the five commonly used Vitis vinifera $\mathrm{L}$. reference genes, showed stable expression in all experiments, confirming that their selection for the normalization process was appropriate.

\section{Conclusion}

In conclusion, the comparative analysis of the obtained results revealed that the more productive vineyards are those showing higher soil enzyme activities, together with neutral $\mathrm{pH}$, higher TOC content and appropriate $\mathrm{C} / \mathrm{N}$ ratio. These soils also showed a high degradation level of threads, which could be considered as a practical and inexpensive novel index of soil microbial activity as well as a valuable predictive tool for plant performance and soil fertility. In vineyard 1, characterized by low productivity and sub-optimal values for the above parameters, leaf nitrogen and sulfur deficiency resulted as being associated with the overexpression of WRKY, SuSy, PAL and STS1 genes, which are related to physio-metabolic stress in plants. Therefore, the biodegradation level of the threads correlated well with specific profiles of the soil bacterial communities and with the expression of four defense-related plant genes; these parameters represent valuable molecular indicators of the nutritional status of the vine plant.

\section{Abbreviations}

TOC Total organic carbon. ARISA Automated Ribosomal Intergenic Spacer Analyss. PCA Principal Component Analysis.

\section{Acknowledgments}

The research was supported by Veneto Region through the RISIB Project. Alessandro Zonin is gratefully acknowledged for support. The authors wish to thank the Zonin wine making company for hosting the research by allowing the sampling in their wineyards and providing the harvest data.

\section{References}

AFES. 1992. Référentiel Pédologique. Principaux sols d'Europe. Ed. D, Baize and M.C, Girard. INRA Editions, Paris.

Andrés-De Prado, R.,Yuste-Royas, M., Sort, X., Andrés-Lacueva, C., Torres, M., LamuelaRaventòs, R.M. 2007. Effect of soil type on wines produced from Vitis vinifera L.Cv. Grenache in commercial vineyards. J. Agr. Food .Chem. 55,779-786.

Badian, N.N.Y., Chotte, J.L., Pate, E., Masse, D., Rouland, C. 2001. Use of soil enzyme activities to monitor soil quality in natural and improved fallows in semi-arid tropical regions. Appl. Soil Ecol. 18, 229-238.

Bertazzon, N., Raiola, A., Castiglioni, C., Gardiman, M., Angelici, E., Borg, M., Ferrari, S. 2012. Transient silencing of the grapevine gene VvPGIP1 by agroinfiltration with a construct for RNA interference. Plant Cell Rep. 31, 133-143. 
Cardinale, M., Brusetti, L., Quatrini, P., Borin, S., Puglia, A.M., Rizzi, A., Zanardin., Sorlini, C., Corselli, C., Daffonchi, D. 2004. Comparison of different primer sets for use in Automated Ribosomal Intergenic Spacer Analysis of complex bacterial communities. Appl. Environ. Microbiol. 70, 6147-6156.

Coleman, D.C., Whitman, W.B. 2005. Linking species richness, biodiversity and ecosystem function in soil systems. Pedobiologia. 49, 479-497.

Ferrer, J.L., Austin, M.B., Stewart Jr, C., Noel, J.P. 2008. Structure and function of enzymes involved in the biosynthesis of phenylpropanoids. Plant Physiol. Biochem. 46, 356-370.

Florenzano, G. 1986. Fondamenti di microbiologia del terreno. Edizioni Reda, Roma.

Fornasier, F., Margon, A. 2007. Bovine serum albumin and Triton X-100 greatly increase phosphomonoesterases and arylsulphatase extraction yield from soil. Soil Biol. Biochem. 39, 2682-2684.

Fregoni, M. 2009. Atlante nutrizionale della vite. Edizioni Tecniche Nuove, Milano.

Gamm, M., Héloir, M.C., Kelloniemi, J., Poinssot, B., Wendehenne, D., Adrian, M. 2011. Identification of reference genes suitable for qRT-PCR in grapevine and application for the study of the expression of genes involved in pterostilbene synthesis. Mol. Genet. Genomics. 285, 273-285.

Gee, G.W., Bauder, J.W. 1986. Particle-size analysis. In Methods of analysis Part 1. Physical and mineralogical methods. Ed. A, Knute. Agronomy monograph No 9, Soil Science Society of America, Madison, WI. pp. 383-411.

Hol, W.H.G., de Boer, W., Termorshuizen, A.J., Meyer, K.M., Schneider, J.H.M., van Dam, N.M., van Veen, J.A., van der Putten, W.H. 2010. Reduction of rare soil microbes modifies plant-herbivore interactions. Ecol. Lett. 13, 292-301.

Hren, M., Ravnikar, R., Brzin, J., Ermacora, P., Carraio, L., Bianco, P.A., Casati. P., Borgo, M., Angelici, E., Rotter, A., Gruden, K. 2009. Induced expression of sucrose synthase and alcohol dehydrogenase I genes in phytoplasma-infected grapevine plants grown in the field. Plant Pathol. 58, 170-180.

IUSS. Working Group WRB. 2006. World reference base for soil resources 2006, 2nd edn. World Soil Resources Report No. 103, FAO, Rome.

Kemp, B.P., Beeching, R., Cooper, R.M. 2005. cDNAAFLP reveals genes differentially expressed during the hypersensitive response of cassava. Mol. Plant Pathol. 6, 113-123.

Lau, J.A., Lennon, J.T. 2011. Evolutionary ecology of plant-microbe interactions: soil microbial structure alters selection on plant traits. New Phytol. 192, 215-224.

Li, L. 2003. Using PCR and 16S rDNA Hybridization to assess for the presence of Nitrosococcus oceani in a wastewater treatment bioreactor. J. Exp. Microbiol. Immunol. 4, 15-19.

Livak, K.J., Schmittgen, T.D. 2001. Analysis of Relative Gene Expression Data Using RealTime Quantitative PCR and the 2- $\Delta \Delta \mathrm{Ct}$ Method. Methods. 25, 402-408.

MacKenzie, D.J., Mclean, M.A, Mukerji, S., Green, M. 1997. Improved RNA extraction from woody plants for the detection of viral pathogens by reverse transcription-polymerase chain reaction. Plant Dis. 81, 222-226.

Marchive, C., Mzid, R., Deluc, L., Barrieu, F., Pirrello, J., Gauthier, A., Corio-Costet., M.F., Regad, F., Cailleteau, B., Hamdi, S., Lauvergeat, V. 2007. Isolation and characterization of a Vitis vinifera transcription factor, VvWRKY1, and its effect 
on responses to fungal pathogens in transgenic tobacco plants. J. Exp. Bot. 58, 1999-2010.

Marschner, H. 1995. Mineral nutrition of higher plants. second edition. Academic Press, London.

Mengel, K., Kirkby, E.A. 2001. Principles of plant nutrition. Kluwer Academic Publishers, Dordrech.

Oliver, D.P., Bramley, R.G.V., Riches, D., Porter, I., Edwards, J. 2013. Review: soil physical and chemical properties as indicators of soil quality in Australian viticulture. Austr. J. Grape Wine Res. 19, 129-139.

Pandey, S,P., Somssich I E 2009 The role in WRKY transcription factors in plants immunity. Plant Physiol. 150, 1648-1655.

Ranjard, L., Poly, F., Lata, J.C., Mougel, C., Thioulouse, J., Nazaret, S. 2001. Characterization of bacterial and fungal soil communities by automated ribosomal intergenic spacer analysis fingerprints: biological and methodological variability. Appl. Environ. Microbiol. 67, 4479-4487.
Reynolds, H., Packer, A., Bever, J.D., Clay, K. 2003. Grassroots ecology: plant-microbe-soil interactions as drivers of plant community structure and dynamics. Ecology. 84, 2281-2291.

Rodriguez, R. J., Henson, J., van Volkenburgh, E., Hoy, M., Wright, L., Beckwith, F., Kim, Y.O., Redman, R.S. 2008. Stress tolerance in plants via habitat-adapted symbiosis. ISME J. 2, 404-416.

Sharma, V.A.K., Krishnan, D., Budhihal, S.L. 1987. Laboratory methods. National Bureau of Soil Survey and Land Use of Planning Publ. No. 14 (ICMR). Nagpur, India.

Schmidt, H.P., Kammann, C., Niggli, C., Evangelou, M. W. H., Mackie, K.A., Abiven, S. 2014, Biochar and biochar-compost as soil amendments to a vineyard soil: influences on plant growth, nutrient uptake, plant health and grape quality. Agr. Ecosyst. Env. 191, 117-123.

Schmittgen, T.D., Livak, K.J. 2008. Analyzing realtime PCR data by the comparative CT method. Nat. Protoc. 3, 1101-1108. 